\title{
A Study of the factors leading to truancy among adolescent students in district Faridabad
}

\author{
Ms. Neelam Chawla Gosain \\ Research Scholar, Department of Education, Lingaya's University, Faridabad, Haryana, India.
}

\begin{abstract}
The present investigation was undertaken to study the factors that causes truancy among adolescent students. A total of 200 students within the age of 15-18 years from four government schools were purposively selected as sample from Faridabad town of Haryana. Youth Problem Inventory (Y.P.I) of Dr. (Mrs.) Mithlesh Verma was used to administer the factors leading to truancy. Two areas were taken under consideration in the study that is family problems and school problems. The study revealed that family problems and school problems both act as the factor causing truancy among students and out of two family problems is more effective in causing truancy among students.
\end{abstract}

Keywords: adolescents, diagnosis, phobia, truants, truancy

\section{Introduction}

Child takes birth as a helpless creature and he is not able to stand and talk at the time of birth; he has to learn these activities. Nature has made human life capable of gaining a lot of knowledge. From this point of view, it is natural right of a child to receive a proper education. Education is that light which expels darkness from life and focuses attention in all round development of the child, not only in the present age, but also in the past. It is not only important to admit the children to schools and providing facilities for them but it is also important to prevent wastage and stagnation of those who have been admitted to schools. Truancy is the main cause of wastage and stagnation.

\subsection{Meaning of Truancy}

The word truancy means "Run away from the classes" and the students who always tend to keep themselves away from studies and avoid attending classes are called truants. Truant Students develop a sort of Schools-Phobia. School phobia is a fear which may approach panic, of leaving home and going to schools. It should not be confused with the occasional mild reluctance for school seen in normal children and adolescents, or with realistic fears of going to school. Truancy is the main cause of wastage and stagnation. Truancy leads to poor result in the examinations, failures, non-promotion and drop outs which is technically called "Wastage and Stagnation" in education.

According to Kothari commission (1964-66) "Wastage and Stagnation" are the symptoms ailment due to which there is absence of proper relationship between life and attraction for children to be in School".

Truancy is the exclusively professional concern of teachers for educational welfare. The range of people who could be involved in a treatment decision is very broad; they include teachers, parents, educational welfare officers, educational Psychologists, Social workers, magistrates, and psychiatrists. What type of action will be taken depends on a number of factors and the definition of the child's problem and largely depends on the profession in which he/she is involved.

Truancy may also results in juvenile delinquency. There are many types of delinquent acts; truancy is included under the act of 'Tendency to escape'. A truant student finds himself like a prisoner in jail. Every thing at school seems mechanical. He runs from the situation i.e. truancy from school and running from home.

\subsection{Factors Hindering Mental Health of the Students}

Modern psychology has shown that the most important factor for a child's healthy development is affection and sense of security. Both over protection and rejection of the child by the parents have an adverse effect on his adjustment. Other factors in the family are sibling rivalry, conflicts between parents, faulty parental models, and unrealistic expectations of parents from the child also negatively influence the children's personality and adjustment. And as a result, his super ego gets defective and full of contradictions. Education is the key to social, economic, and cultural development of a country. A child's education started as soon as he is conceived. His first curriculum starts in the contact of his mother, the way he is handled and cared for his personality formation starts taking place in proportion to that of his mother after the mother child comes in the contact of other family members who make a home. Home is the primary group which shapes the individuality, character, and personality of the child. Society is the secondary group which helps in the socialization of the child. No doubt, other than the Home and Society, it is the education which affects the all round development of 
a child. As the school is next only to home that influence personality and emotional development of the child. But the school may turn out to be a source of constant trouble, worry and anxiety. He has to bear new types of pressures such as pressure to pass the examination, to be best with his school work to form good relations with his peer group and teachers, to secure praise, recognition, and status in school. When instead of receiving sympathetic attention he receives insult, taunts, and rebukes. It affects his mental health. It becomes a major factor of disinterestedness in school.

\subsection{Significance of study}

Truancy is a phenomenon which can be observed in most Government schools whether Primary, Secondary or Senior Secondary. This state leads to education stagnation. As a result of continuous absence from the school which is known as truancy either the child drops before completing his schooling or fails in a particular class. A number of investigators have ventured to go into the etiology of truancy in India. This is really a big problem and both parents and teachers are most concerned about truants and want to solve their problem so that the high percentage of absentees may be reduced. It helps us in reducing the wastage and stagnation in education. So, the present investigator decided to take this particular topic.

The objectives of the present study were as follows:

1. To find out the problems in family leading to truancy among students.

2. To find out the problems at school leading to truancy among students.

3. To find out the different areas of youth problems leading to truancy among students.

The following Hypothesis was formulated:

\section{Hypothesis}

1. Problems in family are related to truancy.

2. Problems in school are related to truancy.

3. Certain areas of youth problems are responsible for truancy.

\section{Review of related literature}

Some of the studies related to truancy are discussed below:

Ferguson in 1952 conducted a study on Glasgow-School leavers and produced the results that truants did more detected crimes than regular school attending students.

Francies A.Muller (1958) tried to compare truancy with the classroom disorders. He states that unhappiness, unsuccessfulness is responsible for making a child, a truant, and physical conditions also affect the truancy rate. Home and community environment play an important role in the development of the child. He observes that truancy is the result of classroom disorders, home problems, such as grade retardation, reading disability and personality problems.

Chauhan N.S. (1978) did the comparative study of truants and non truants. Most of the characteristics of delinquency arise out of truancy. Truancy results in delinquency. The phenomenon of truancy appears to be grounded in none accepting to school as extensions of home.

Bahuguna B.D (1980) made a study of cause of irregular attendance in a few selected schools of Delhi. The investigator concludes that truancy is due to following causes: Poor Achievement, Poverty and in some cases early marriage and poor study atmosphere, Dislike for teacher and curriculum, Administrative Laxity.

Sharma T.R (1981) made a survey of the problem of truancy among high school students. He observed that truants are mostly boys and they are generally quite healthy. Main contributing factors are uneducated father, illiterate mother, over crowded houses, bad economic conditions, low intelligence, and bad company.

Parmel Yadav (1988) did his investigation on finding all the causes of truancy of the students of reward. The main causes which strike most were: family cause, academic cause, economic cause, social cause, natural calamities defective teaching and miscellaneous cause. To reduce the truancy rate, Parents and teachers should be guided properly.

Mangal S.K. (1997) in the first Edition of his book "Our Life And Psychology" gave some factors which are responsible for truancy:-

- Weak physical health of child

- Undeveloped mental health of the child

- Non-cooperative behaviour of teachers

- Indiscipline prevalent in the school.

- Lack of interesting and co curricular activities

- Social and emotional maladjustment 
The main report of sixth All India Educational Survey by N.C.E.R.T,(1999) shows that Per student expenditure in all types of schools (in Rs.) in Haryana is 893.19 While in Government schools per student expenditure (in Rs.) is 865.46.Truancy is one of the hindrance in proper utilization of this expenditure.

Hardre and Reeve (2003) find that a combination of three factors successfully predicted that $27 \%$ of the variation in attitude towards dropping out. One of those factors alone school performance predicts $17 \%$ of the variation in drop out intentions.

Mac Gillivary \& Mann-Erickson, (2006) find that truant youth contribute significantly to the incidence of day time crime. Data from National incidence reporting system indicate that the number of crimes committed by school hours exceed those after school.

M.V.R Raju and Digumarati Bhaskara Rao (2007) in their book "Behavioral problems of school children" states that, the influencing factors for these behavioral problems are socio economic background, television, cinema, and defective child rearing practices.

The global school based survey (2008) by Ster Siziya, Adamen. S. Mulla \& Emmoanuel Rudatsirikira finds that, Truancy was associated with lower school grade, having been victim of bullying, having gone hungry sometimes because of lack of food at home and less parental observation.

They found that adolescent who reported parental supervision and support were less likely to be truant than those who lacked social support.

\section{Plan and procedure of the study}

5.1 Method: Keeping in view, the nature and purpose of the study at hand, the investigator used the survey method. The study was carried out in Faridabad district of Haryana. To cover adolescent stage the students from class IX to XII were taken from Four Government senior secondary schools. 200 students (boys and girls) formed the sample. 50 students from each school were selected randomly.

\subsection{Selection of the Tool:}

Youth Problem Inventory (Y.P.I) of Dr. (Mrs.) Mithlesh Verma was administering inventory for the students of 16 to 20 of age of Hindi speaking areas to find out the factors causing truant tendency. The inventory contains 80 statements belonging to the under mentioned 4 areas and a number of Sub-areas under each main area. Area A- Family Problems, Area B- School/College Problems, Area C-Social Problems, Area D- Personal Problems and Over Sensitivity. In present study only area A\&B are taken under consideration.

Table 1: shows Reliability coefficient of all Areas of Inventory.

\begin{tabular}{|c|c|}
\hline Areas & Reliability Coefficient \\
\hline A & 0.85 \\
\hline B & 0.86 \\
\hline C & 0.76 \\
\hline D & 0.81 \\
\hline Entire Inventory & 0.80 \\
\hline Range & $0.76-0.86$ \\
\hline
\end{tabular}

5.3 Statistical Analysis: statistical measures such as mean and percentage were used to interpret the obtained data.

\subsection{Analysis of Data and Interpretation}

In order to give the present study a meaning and a desired shape and direction, the data were subjected to statistical procedure.

Table 2: shows the family problems leading to truancy. Family problem area 'A; is divided into 14 sub areas comprising of 31 statements. The respective codes for statement and percentage of each sub area are given in the table.

Table 2: Area A: Family Problem (Scoring and Percentage)

\begin{tabular}{|l|l|c|c|c|}
\hline Sr. No. & Code & $\begin{array}{l}\text { Obtained Scores of Total } \\
\text { students(200) in each sub area }\end{array}$ & $\begin{array}{l}\text { Maximum scores of sub area for } \\
\text { 200 students }\end{array}$ & $\begin{array}{l}\text { Percentage (\%) of obtained score } \\
\text { of total students }\end{array}$ \\
\hline 1. & AI & 224 & 800 & $28 \%$ \\
\hline 2. & AS & 296 & 1200 & $24.66 \%$ \\
\hline 3. & AC & 218 & 1200 & $18.16 \%$ \\
\hline 4. & AD & 396 & 1200 & $33 \%$ \\
\hline 5. & AIN & 330 & 1200 & $27.50 \%$ \\
\hline 6. & ADO & 130 & 800 & $16,25 \%$ \\
\hline 7. & AM & 112 & 800 & $14 \%$ \\
\hline
\end{tabular}




\begin{tabular}{|l|l|l|l|l|}
\hline 8. & AR & 76 & 800 & $9.50 \%$ \\
\hline 9. & AF & 192 & 800 & $24 \%$ \\
\hline 10. & AP & 326 & 800 & $40.75 \%$ \\
\hline 11. & AA & 64 & 800 & $8 \%$ \\
\hline 12. & AO & 252 & 800 & $31.50 \%$ \\
\hline 13. & AG & 118 & 400 & $29.50 \%$ \\
\hline 14. & ASR & 104 & 800 & $13 \%$ \\
\hline
\end{tabular}

Mean percentage $(\%)$ of Area 'A'= $2838 \times 100 / 12400=\mathbf{2 2 . 8 8 \%}$

Table-2: shows that to what extent the students (truants) are being affected by various family problems. The details of various codes are as follows:

Code:

$\begin{array}{ll}\text { AI } & \text { Parental indifference } \\ \text { AS } & \text { Parental strict supervision and lack of freedom } \\ \text { AC } & \text { Criticism and lack of recognition by parents } \\ \text { AD } & \text { Demands by family } \\ \text { AIN } & \text { Interference } \\ \text { ADO } & \text { Parental dominance } \\ \text { AM } & \text { Maintenance of difference between sons and daughter } \\ \text { AR } & \text { Rejection by parents } \\ \text { AF } & \text { Fear of parents } \\ \text { AP } & \text { Projection by parents } \\ \text { AA } & \text { Lack of affiliation } \\ \text { AO } & \text { Over dependence on parents } \\ \text { AG } & \text { Inter-generation gap in ideology } \\ \text { ASR } & \text { Sibling relations }\end{array}$

\section{Graph 'A' Presents the Factors Related to Family Problems}

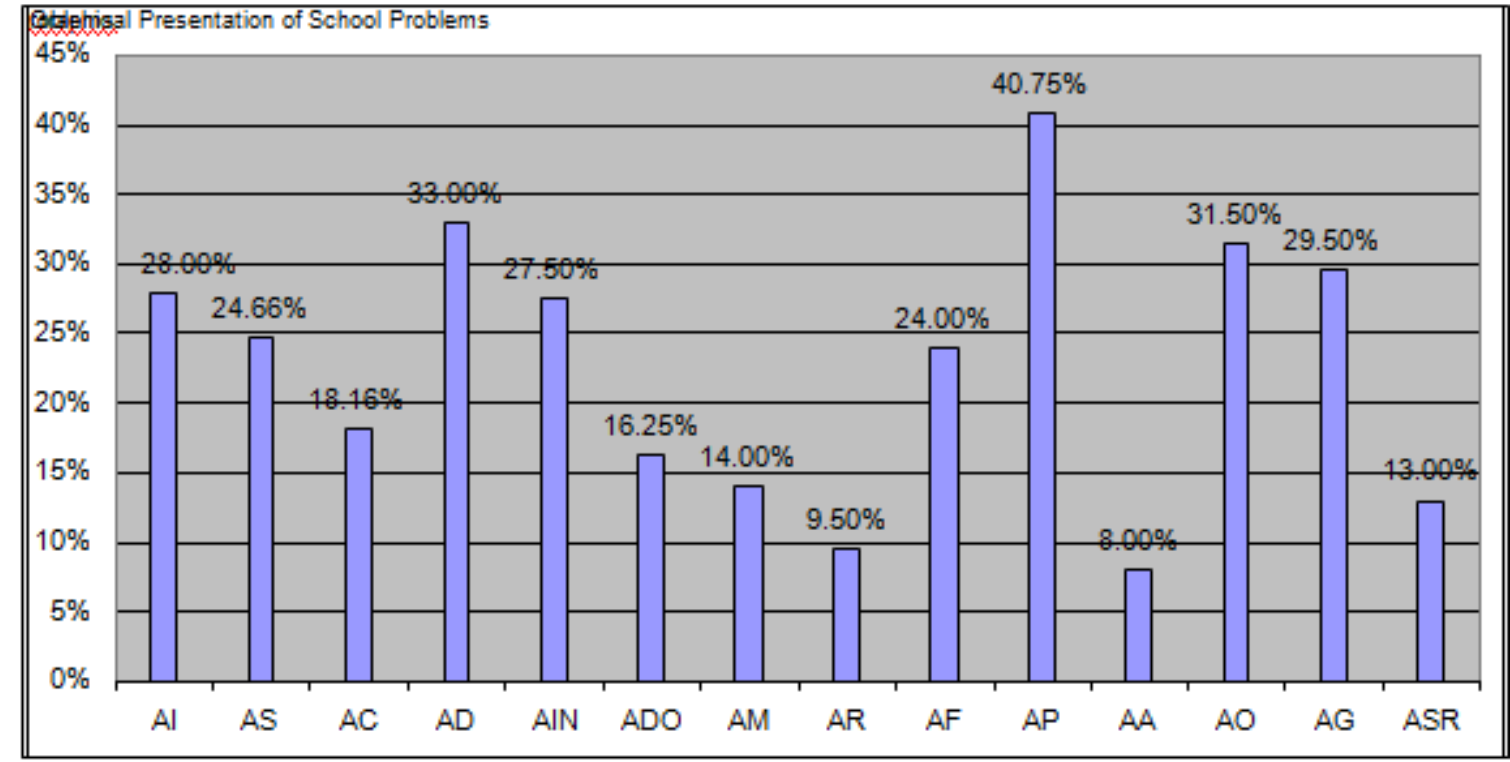

Problems code of various sub areas (Area A)

Interpretation: From table-2 it is observed that

i) Code 'AI' which means parental difference is effective up to $28 \%$.

ii) Code 'AS' which means parental strict supervision and lack of freedom is effective up to $24.66 \%$.

iii) Code ' $\mathrm{AC}$ ' which means criticism and lack of recognition by parents is effective up to $18.16 \%$

iv) Code 'AD' which means demands by family is effective up to $33 \%$.

v) Code 'AIN' which means interference is effective up to $27.50 \%$.

vi) Code 'ADO; which means parental dominance is effective up to $16.25 \%$.

vii) Code 'AM' which means maintenance of difference between son and daughter is effective up to $14 \%$

viii) Code 'AR' which means Rejection by parents is effective up to $9.50 \%$

ix) Code 'AF' which means Fear of parents is effective up to $24 \%$.

x) Code 'AP' which means Projection by parents is effective up to $40.75 \%$. 
xi) Code 'AA' which means Lack of affiliation is effective up to $8 \%$

xii) Code 'AO' which means Over dependence on parents is effective up to $31.50 \%$

xiii) Code 'AG' which means inter-generation gap in ideology is effective up to $29.50 \%$

xiv) Code 'ASR' which means Sibling relations is effective up to 13.

xv) Code 'AP' which means projection by parent is more effective $40.75 \%$

xvi) Code 'AP' which means projection by parents is more effective i.e.40.75\%.

xvii) Code 'AA' which means lack of affiliation least effective i.e. to the extend of $8 \%$

Table 3 - Area-B: School Problems

\begin{tabular}{|c|c|c|c|c|}
\hline $\begin{array}{l}\text { Sr. } \\
\text { No. }\end{array}$ & $\begin{array}{l}\text { Problem } \\
\text { Code }\end{array}$ & $\begin{array}{l}\text { Obtained Scores of Total } \\
\text { students (200) in each sub } \\
\text { areas }\end{array}$ & $\begin{array}{l}\text { Maximum Score of each } \\
\text { sub area for } 200 \text { students }\end{array}$ & $\begin{array}{l}\text { Percentage of }(\%) \text { obtained } \\
\text { score of total students. }\end{array}$ \\
\hline 1. & $\mathrm{BF}$ & 94 & 400 & $23.5 \%$ \\
\hline 2. & BFT & 214 & 1200 & $17.83 \%$ \\
\hline 3. & BR & 122 & 800 & $15.25 \%$ \\
\hline 4. & $\mathrm{BI}$ & 112 & 800 & $14 \%$ \\
\hline 5. & $\mathrm{BH}$ & 176 & 1600 & $11 \%$ \\
\hline 6. & BIS & 192 & 1200 & $16 \%$ \\
\hline 7. & $\mathrm{BS}$ & 226 & 1200 & $18.83 \%$ \\
\hline 8. & BHA & 208 & 800 & $26 \%$ \\
\hline
\end{tabular}

Mean \% of Area B $=1344 \times 100 / 8000=16.8 \%$

Table-3: shows that to what extent the students (truants) are being affected by various schools problems. The details of various codes are as follows:

Code:

$\begin{array}{ll}\text { BF } & \text { Fear of college/school activities } \\ \text { BFT } & \text { Fear of teachers } \\ \text { BR } & \text { Rejection and indifference by parents } \\ \text { BI } & \text { Incompetence of teachers } \\ \text { BH } & \text { Harsh, rude and sarcastic behaviour of teachers } \\ \text { BIS } & \text { Isolation } \\ \text { BS } & \text { Difficulties in school/college subjects } \\ \text { BHA } & \text { Other handicaps at school/college }\end{array}$

Interpretation: From table- 3 it is observed that

i) Code 'BF' which means Fear of college/school activities is effective up to $23.5 \%$

ii) Code 'BFT' which means Fear of teachers is effective up to $17.83 \%$

iii) code 'BR' which means Rejection and indifference by parents is effective up to $15.25 \%$

iv) Code BI' which means Incompetence of teachers is effective up to $14 \%$

v) Code 'BH' which means Harsh, rude and sarcastic behaviour of teachers is effective up to $11 \%$.

vi) Code 'BIS' which means Isolation is effective up to $16 \%$

vii) Code 'BS' which means Difficulties in school/college subjects is effective up to $18.33 \%$

viii) Code 'BHA' which means Other handicaps at school/college is effective up to $26 \%$

ix) Code 'BHA' is more effective, which means other handicaps at school/college and the code which is least effective is 'BH' which means Harsh, rude and sarcastic behavior of teachers. 
Graph 'B' presents the factors related to school problems

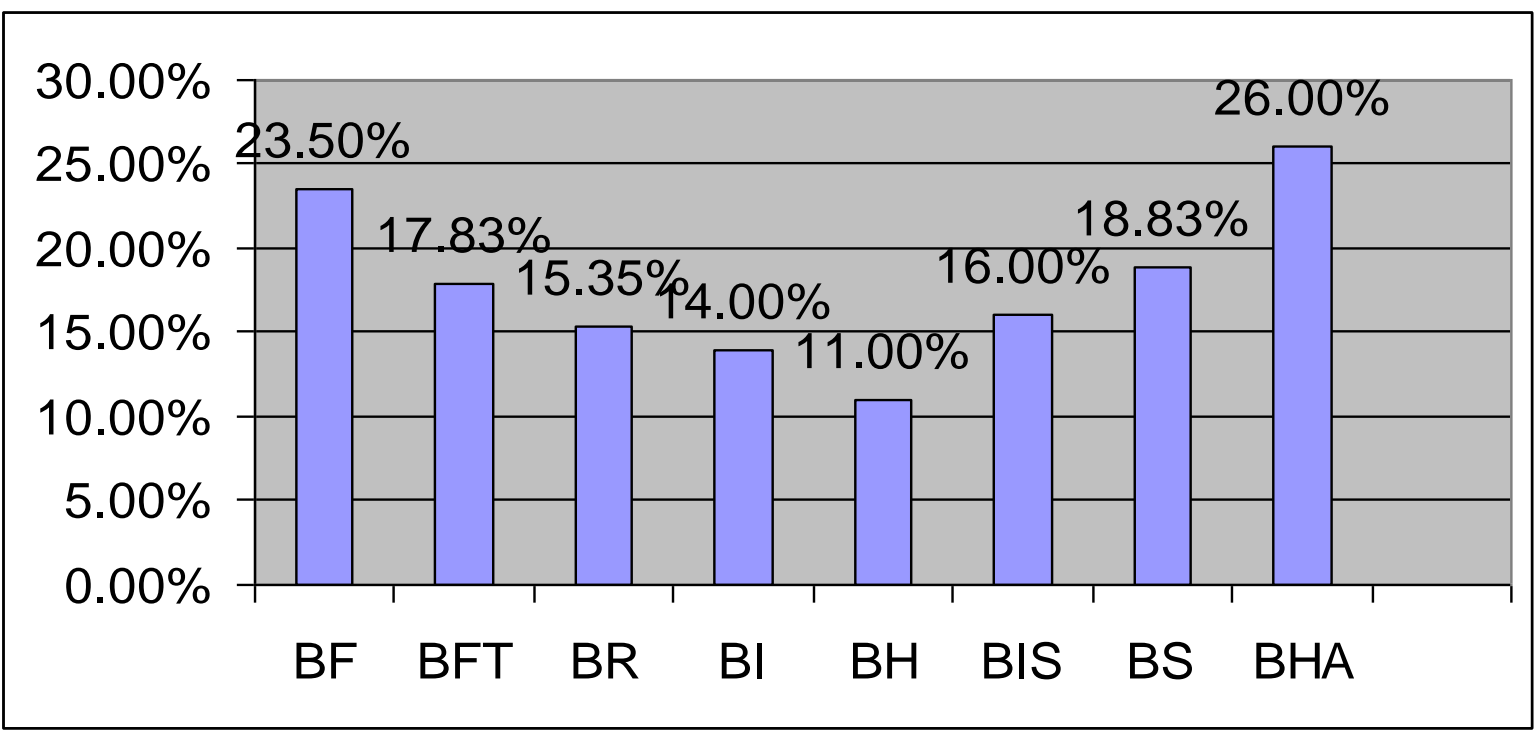

Problems Code of various Sub Areas (Area B)

\subsection{Results \& Discussion}

Table 4- Total areas of youth problem

\begin{tabular}{|c|c|}
\hline Code & Results \\
\hline A & $22.88 \%$ \\
\hline B & $16.8 \%$ \\
\hline
\end{tabular}

Table 4 shows that area A which means Family problems is more effecting than other areas in creating truant tendency. Other areas are also responsible for truant tendency.

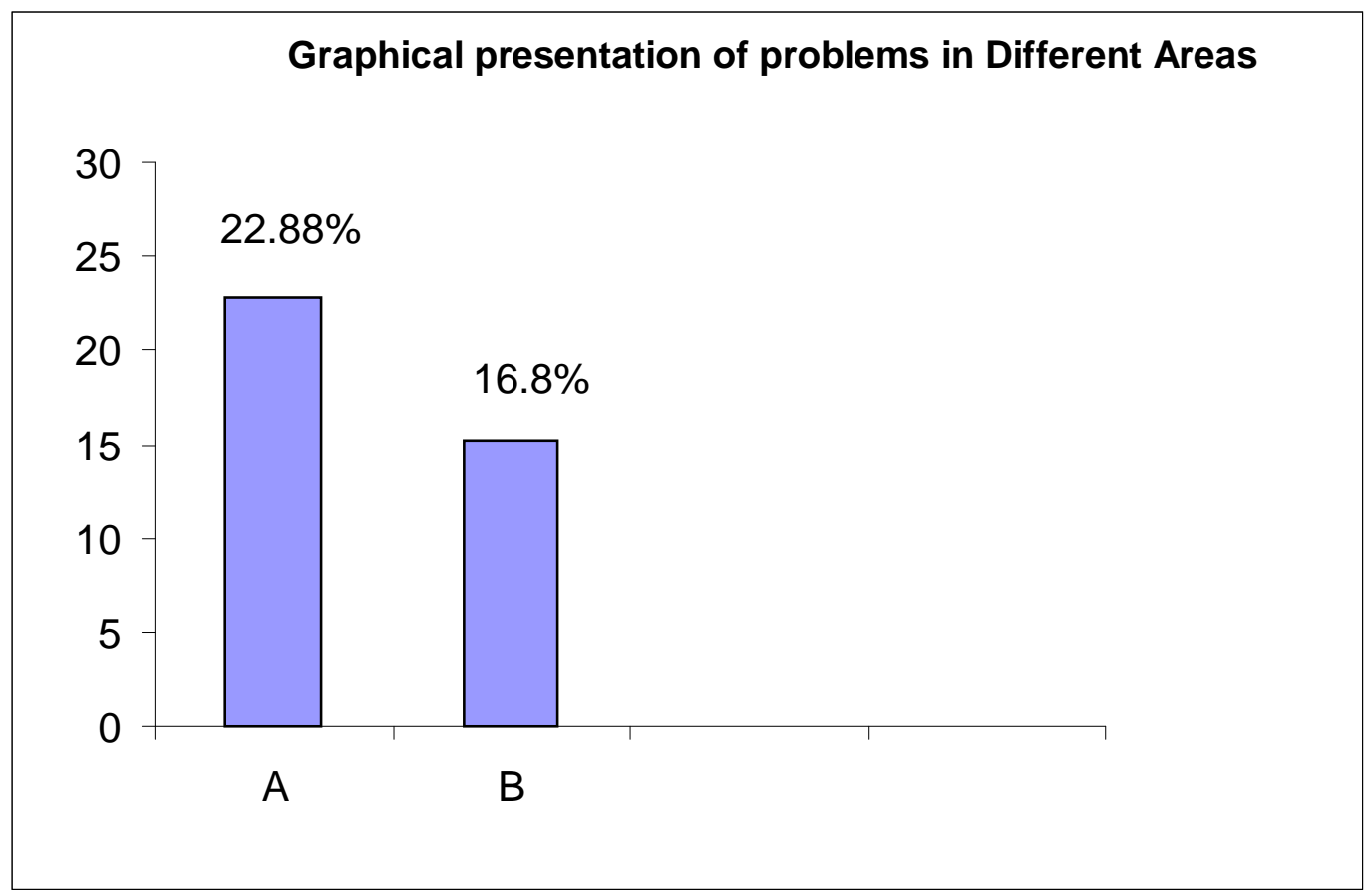

Codes of different Areas of Problems

A $\quad=$ Family Problems

B $\quad=$ School Problems

Most of the students have problems in family problem area. Truants have more or less problem in each sub area of family problem area so our first Hypothesis is retained. In school problem area, each sub area affects 
number of truants. So our second Hypothesis is also retained. In family problem area, the problem of projection by parents is more affecting the students i.e. up to $22.88 \%$. This means that parents want that their children should follow there ideals and fulfill their wishes. In school problem area, the problem of other handicaps is disturbing the students i.e. up to $16.8 \%$. This mean that fewer opportunities are provided at schools for up to date knowledge and subject are not interesting for students. Among the four areas the area which is more dominant is family problems. A particular truant may have problems in only one area or more than one area

\section{Conclusion}

The forgoing discussion has highlighted that family environment and school situations and conditions as the most influential factors in producing truancy among students. Family must be careful in aspiring their children's future. Parents should be given guidance through adult education. A sound knowledge of the correct methods of observation and diagnosis is necessary for a teacher in order to discover the truants. Besides this knowledge the teacher needs to have a keen eye for significant peculiarities of behavior and the necessary experience upon which can draw interpretation of what he observes.

\section{References}

[1]. Adams, P.L.McDonald, (1966), 541-547 "School Phobia and bisexual conflict", American Journal of Psychiatry.

[2]. Garret, Henry E. (1966) "Statistics in psychology and education", Goyal Publishing House, New Delhi.

[3]. Gold, M. (1966) III, 27-46, "Undetected delinquent behaviour". Journal of research in crime and delinquency, United States.

[4]. Kumaria, R.R. (1972) "The Indian child in home and school". Jalandhar university publications, Punjab.

[5]. Agarwal, J.C (1972) "Educational Research- an introduction". New Delhi

[6]. Shankar, Uday (1978) Problematic children, Atma Ram \& Sons, New Delhi.

[7]. Buch, M.B(Ed) (1979) "A Survey of research in education” Baroda, Society of education research.

[8]. Ross, A.O., (1980) "Psychological disorders of children". New York: McGraw Hill.

[9]. Bhatia, H.R., (1983) "Understanding your child”. New Hindustan Publications Karol Bagh, New Delhi.

[10]. Buch, M.B(Ed) (1991) "fifth survey of research in education". 1988-92 vol-I, New Delhi.

[11]. Snary, J. (1993) "How fathers care for the next generation": A four decade study. Cambridge: Harvard university press.

[12]. NCERT, (2007) “Sixth Survey of Education”, National Council of Education and Research, New Delhi.

[13]. Kaul, L (2009) “Fundamentals of Education Research", Vikas Publishing House, Noida.

\section{OTHER REFERENCES:}

- $\quad$ www.eric.edu.gov

- $\quad$ www.ncert.nic.in

- www.scertharyana.in 